\title{
РОЛЬ НАЛОГОВ В ОБЕСПЕЧЕНИИ ЭКОНОМИЧЕСКОЙ БЕЗОПАСНОСТИ РОССИЙСКОЙ ФЕДЕРАЦИИ
}

\author{
(C) 2021 Дождева Елена Евгеньевна \\ кандидат экономических наук, доцент кафедры финансов и кредита \\ Самарский государственный экономический университет, Россия, Самара \\ Email: dozhdeva69@mail.ru
}

В статье определена роль налогов в обеспечении экономической безопасности государства. На основании этого, предлагается наиболее точное определение понятия экономической безопасности государства. Данная статья определяет, что в целях обеспечения экономической безопасности государства необходимо различать объективные показатели, которые проявляются в актуальных количественных данных, и субъективные показатели, определяющие цели, объекты, задачи и результативность деятельности различных ветвей органов государственной власти.

Ключевые слова: экономическая безопасность государства, рыночная экономика, уровень налоговых поступлений, бюджетная система, объективные и субъективные показатели, хозяйствующие субъек$m b l$.

На современном этапе развития рыночных отношений в Российской Федерации роль налогов заключается в обеспечении экономической безопасности государства. Проанализировав труды ученых-экономистов установлено, что теоретические и практические аспекты роли налогов в обеспечение экономической безопасности раскрыты не в полной мере. В частности, отсутствует формулировка понятия экономической безопасности с учетом объективных и субъективных показателей, способствующих обеспечению экономической безопасности государства. Также недостаточно сформулированы факторы риска для экономической безопасности государства. К самым значимым инструментам обеспечения экономической безопасности государства относятся налоги. Налоговые платежи принимают активное участие в перераспределение национального дохода государства, выступая формой производственных отношений, которые формируют общественное содержание налогов. Кроме общественного содержания налоги функционируют с помощью материальной основы, которая заключается в том, что налоги представляют собой объем денежных ресурсов, поступающих в бюджеты разных уровней бюджетной системы государства.

В условиях рыночной экономики основная роль налогов в обеспечение экономической безопасности государства возрастает, так как это один из значимых фискальных инструментов государственного регулирования экономики и социальных процессов. Налоги оказывают воздействие на экономическую безопасность государства через систему определенных форм, методов и инструментов управления налогообложением и налоговыми доходами бюджетов различных уровней. Государство использует налоги в следующих целях:

1. Изъятия у хозяйствующих субъектов и населения части их дохода в свою пользу для обеспечения экономической безопасности государства;

2. Для стимулирования или сдерживания объемов производства хозяйствующих субъектов, а также увеличения или уменьшения платежеспособного спроса населения.

В современных условиях развития рыночных отношений большое значение имеет обеспечение экономической безопасности государства. Основным риском, оказывающим отрицательное воздействие на экономическую безопасность государства, является функционирование теневой экономики. Структуры теневой экономики не выполняют обязанности по исполнению налоговых обязательств перед государством. Таким образом, экономическая безопасность государства представляет собой систему мер, направленную на обеспечение определенного объема налоговых доходов, поступающих в бюджеты разных уровней государства для результативного выполнения государством своих функций и полномочий. При определении приоритетных направлений по 
повышению экономической безопасности, государство также должно учитывать финансовые ресурсы теневого сектора экономики и уровень расходов на социальные процессы.

Таким образом, налоговые обязательства являются основной частью сегмента экономической безопасности, во-первых, как ресурсный показатель, находящийся в руках государства, во-вторых, как элемент регулирования экономических и социальных процессов, в-третьих, как фактор зависимости государства от налогоплательщиков и территорий. В налогах необходимо видеть две стороны: ресурсы и элементы, способствующие обеспечению экономической и финансовой безопасности, с одной стороны, и показатели риска и зависимости - с другой. Как ресурсный показатель налоги могут использоваться государством и как фискальное средство обеспечения экономической безопасности (увеличение уровня налоговых доходов), и как фактор усиления рисков (снижение налоговых доходов в силу определенных причин).

В целях, обеспечения экономической безопасности государства, необходимо определять объективные показатели, которые проявляются в актуальных количественных данных, и субъективные показатели, выражающие цели, объекты, задачи и результативность функционирования различных ветвей органов государственной власти.

Для обеспечения экономической безопасности государства к объективным показателям относятся:

1. Фискальный рост уровня налоговых доходов государства вследствие увеличения налогооблагаемой базы. Это приводит к увеличению доли налоговых доходов в ВВП.

2. Способность современной налоговой системы администрирования фиксировать законодательно установленный объем налоговых обязательств, прежде всего за счет введения новых способов или форм налогообложения. В частности, в НК России зафиксированы специальные налоговые режимы. Специальные налоговые режимы предусматривают полное или частичное освобождение налогоплательщиков от уплаты налоговых платежей по определенным федеральным, региональным и местным налогам.

3. Снижение уровня налоговой нагрузки, так как высокий объем налоговых обязательств снижает экономические возможности субъек- тов хозяйствования по увеличению объемов производства и эффективному развитию предпринимательской активности. В России на современном этапе развития цифровой экономики постоянно вносятся изменения в налоговое законодательство. Это приводит к снижению уровня налоговой нагрузки на субъекты хозяйствования, что способствует росту предпринимательской активности бизнеса и минимизации рисков экономической безопасности.

4. Изменяя налоговые ставки, государство проводит политику экономической безопасности, не затрагивая всей массы законодательства по налогам. Политика экономического безопасности напрямую зависит от эффективных мер в сфере налогообложения, а именно, за счет законодательного регулирования налоговых ставок для определенных категорий юридических и физических лиц в отдельных регионах, отраслях и предприятиях. Ставка налога обеспечивает мобильность налогового законодательства и позволяет государству быстро, эффективно и результативно осуществлять смену приоритетов в процессе налогового администрирования, увеличивая уровень наполняемости бюджетов разных уровней [3].

5. Предоставляя физическим и юридическим лицам те или иные налоговые льготы, государство, прежде всего, активно воздействует на развитие новых секторов экономики, обновление производственных фондов, привлечение инвестиций, снижение налоговой нагрузки и др. Для обеспечения экономической безопасности в период экономических и финансовых кризисов государство вводит определенные налоговые льготы. Это льготы для поощрения концентрации капитала, обновления производственных фондов, стимулирования внешнеэкономической деятельности и повышения плажеспособного спроса населения.

6. Полное или частичное освобождение от уплаты отдельных налогов, используется государствами для развития предпринимательской активности с учетом требований цифровой экономики. Для этого используются налоговые рычаги. Это ускоренная амортизация, отсрочка или рассрочка уплаты налогов и другие виды и формы налоговых освобождений в отношении определенных налоговым законодательством объектов налогообложения или категорий налогоплательщиков [5].

7. Налоговые скидки (вычеты) - это затра- 
ты налогоплательщиков, уменьшающие налоговую базу, а также вычеты из налоговой базы определенных доходов или стоимости объектов налогообложения. Так, в РФ через систему действующих налоговых скидок для физических лиц, государство регулирует уровень личного потребления и платежеспособный спрос населения. Это достигается путем предоставления стандартных, социальных, инвестиционных, имущественных и профессиональных вычетов по налогу на доходы физических лиц. Действующая система налоговых вычетов является стимулом для снижения объемов выплат теневых доходов.

8. Налоговые санкции обеспечивают исполнение налогоплательщиком налоговых обязательств перед бюджетами различных уровней. Современная система налоговых санкций нацеливает налогоплательщика на использование экономически эффективных форм и способов налогообложения.

К субъективным показателям обеспечения экономической безопасности государства относиться тот фактор, что налоговые доходы в целях балансирования доходов и расходов поступают в соответствующий бюджет в виде процентных отчислений от налогов по нормативам, утвержденным на законодательном уровне. Для эффективного распределения конкретных видов налогов между бюджетами разных уровней должны учитываться следующие финансовые показатели:

1. Стабильность: чем в большей степени налоговые поступления зависят от экономической коньюктуры, тем выше должен быть уровень бюджетной системы, за которым закрепляется этот налоговый источник и полномочия по его регулированию.

2. Экономическая безопасность: за каждым уровнем бюджетной системы должны закрепляться налоги, объект и налогооблагаемая база которых зависит от налоговой и экономической политики данного уровня власти.

3. Территориальная мобильность налоговой базы: чем выше возможности для перемещения налоговой базы между регионами, тем на более высоком уровне бюджетной системы должен вводиться соответствующий налог и тем выше предпосылки для централизации данных налоговых поступлений.

4. Равномерность размещения налоговой базы: чем выше неравномерность размещения налоговой базы, тем на более высоком уровне должен вводиться соответствующий налог и тем выше предпосылки для централизации данных налоговых доходов.

5. Социальная справедливость: налоги, носящие перераспределительный характер, должны быть в основном закреплены за федеральным уровнем власти.

В настоящее время, приняты меры к усилению финансовой самостоятельности регионов и органов местного самоуправления с целью предотвращения факторов риска для экономической безопасности государства. Для этого законодательно утверждены нормативы распределения доходов от поступлений по федеральным налогам между федеральным, региональными и местными бюджетами. На современном этапе все муниципалитеты имеют систему гарантированных налоговых поступлений, включающих в себя как местные налоги, так и твердо закрепленные за ними доли других налогов. Кроме того, субъектам РФ предоставлено право, передавать местным бюджетам дополнительно часть любого налога, подлежащего зачислению в региональный бюджет по единым нормативам на постоянной основе, то есть без ограничения срока. Это предопределяет устойчивость поступления налоговых доходов в бюджетную систему РФ и создает возможности для их стабильного роста, обеспечивая экономическую безопасность государства.

Несмотря на принятые меры, экономическая безопасность государства имеет факторы риска, так как в РФ высокая степень концентрации налоговых источников доходов в федеральном бюджете, что снижает экономическую безопасность регионов. Федеральные налоги, количество которых вдвое превышает число региональных и местных налогов, играют весомую роль в формировании не только федерального бюджета, но и бюджетов территорий. Таким образом, на долю доходов от федеральных налогов, поступающих по нормативам в бюджеты субъектов РФ и местные бюджеты приходиться более 86\% налоговых доходов этих бюджетов [4].

Кроме небольшого количества, региональные и местные налоговые обязательства незначительны и по своей фискальной величине. Отнесенные на региональный и местный уровни имущественные налоги, в общей сумме которых 95\% приходиться на налог на имущество организаций, обеспечивают менее $20 \%$ поступлений 
доходов в бюджеты субъектов РФ [4].

Таким образом, функционирующие в настоящее время особенности распределения налоговых доходов между бюджетами бюджетной системы, отрицательно воздействуют на экономическую безопасность страны, а главное на способности федеральных властей и органов местного самоуправления оказывать влияние на рост экономического потенциала региона и муниципалитета, создавать привлекательный инвестиционный климат на подведомственной территории. На наш взгляд, при таком незначительном финансовом значении региональных и местных налогов, субъекты Федерации и органы местного самоуправления практически лишены статуса субъекта самостоятельной налоговой политики, то есть одного из наиболее функциональных рычагов снижения факторов рисков для экономической безопасности государства в условиях развития современной цифровой экономики. Из-за небольшого количества и незначительной фискальной величины региональных и местных налоговых платежей, возможности участия органов государственной власти субъектов РФ и органов местного самоуправления в формировании налоговых доходов бюджетов территорий недостаточны, что является значимым фактором риска для обеспечения экономической безопасности государства.

\section{Библиографический список}

1. Барулин С. В. Финансы: учеб. для вузов - М.: КноРус, 2017.-640с.

2. Грязнова А.Г., Маркина Е. В. Финансы: учеб. для вузов - М.: Финансы и статистика,2012.-496с.

3. Миляков Н.В. Налоги и налогообложение: учеб, для вузов - М.: Инфа-М,2009. - 509с.

4. Ордынская Е. В. Налоги и налогообложение: учебник для бакалавров - М.: Проспект, 2017. - 243c.

5. Пансков В.Г. Налоговая система РФ: проблемы становления и развития: учебник для бакалавров - М.: Вузовский учебник, 2018. - 459c.

6. Подъяблонская Л. М. Финансы: учеб. для вузов - М.: Учебник,2011.-390с.

7. Романовский М.В., Врублевская О. В. Налоги и налогообложение: учеб. для вузов - М.: Питер,2012.-528c.

8. Романовский М.В. Налоги и налогообложение: учебник для академического бакалавриата - М.: Юрайт,2015.-496с. 